\title{
STIMULATORY EFFECTS OF ANTIANDROGENS ON LNCaP HUMAN PROSTATE TUMOR CELL GROWTH, EGF-RECEPTOR LEVEL AND ACID PHOSPHATASE SECRETION
}

\author{
A. L. G. Schuurmans, ${ }^{*}$ J. Bolt, J. Veldscholte and E. Mulder \\ Department of Biochemistry, Division of Biochemical Endocrinology, Erasmus University Rotterdam,
} P.O. Box 1738, 3000 DR Rotterdam, The Netherlands

\begin{abstract}
Summary - LNCaP cells (derived from a lymph node carcinoma of the human prostate) show androgen responsive growth. Progestagens, estradiol and antiandrogens competed with androgens for binding to the androgen receptor in the cells to a higher extent than in other androgen-sensitive systems. Optimal growth (3-4 fold increase in DNA content of 6 day cell cultures vs controls) was observed after addition of the synthetic androgen R1881 (0.1 nM). Both steroidal and non-steroidal antiandrogens did not suppress the androgen responsive growth. At a concentration of $10 \mathrm{nM}$ cyproterone acetate or $100 \mathrm{nM}$ RU 23908, growth was even stimulated to an extent comparable to that observed after addition of androgen. Cyproterone acetate and RU 23908 also increased the number of epidermal growth factor receptors expressed at the cell surface to a comparable level as did the androgen. Like androgens, cyproterone acetate, RU 23908 or estradiol stimulated the secretion per cell of prostate specific acid phosphatase in the culture fluid. In conclusion, antiandrogens can exert striking stimulatory effects on the proliferation of $\mathrm{LNCaP}$ cells probably due to a defective androgen receptor system. It is discussed that comparable changes in the specificity of the androgen receptor in prostate cancer cells may give these cells an advantage in growth rate and may contribute to development of tumors characterized as hormone independent.
\end{abstract}

\section{INTRODUCTION}

Among the six permanent growing human prostate cell lines described up to now [1] only the LNCaP (lymph node carcinoma of the prostate) cell line developed by Horoszewicz et al. [2] shows androgen dependent growth [2-5]. This increase in growth rate is not due to neutralization of serum factors as has recently been suggested [6]; an increase in growth rate by androgens is also seen in growth factor inactivated or serum-free medium [7]. LNCaP cells contain considerable amounts of androgen receptors while estrogen and progestagen receptors are not detectable. However, estrogens and progestagens compete for binding to the androgen receptor in LNCaP cells and have stimulatory effects on growth of the cells [5].

In the present study the effects of a steroidal (cyproterone acetate) and non-steroidal (RU 23908) antiandrogen on LNCaP cell prolifer-

Proceedings of the 2nd International EORTC Symposium on "Hormonal Manipulation of Cancer: Peptides, Growth Factors and New (Anti-)Steroidal Agents", Rotterdam, The Netherlands, 9-1I April 1990.

*Present address: Department of Endocrinology, Wilhelmina Kinderziekenhuis, Utrecht, The Netherlands. ation, secretion of PAP and expression of EGF receptors were investigated. We demonstrate that these androgen-dependent processes were stimulated by antiandrogens.

\section{EXPERIMENTAL}

\section{Materials}

$\left[{ }^{3} \mathrm{H}\right] \mathrm{R} 1881$ (methyltrienolone, $87 \mathrm{Ci} / \mathrm{mmol}$ ), radioinert $\mathrm{R} 1881$ and $\mathrm{R} 5020$ were purchased from New England Nuclear (Boston, MA). Cyproterone acetate was a gift from Schering (Berlin, F.R.G.). RU 23908 (anandron) was a gift from Roussel Uclaf (Paris, France). Triamcinolone acetonide was obtained from Sigma, U.S. Mouse ${ }^{125}$ I labeled EGF (140 Ci/g, Amersham) was used following removal of free iodine by Sephadex G25 gelfiltration.

\section{Tumor cells}

The LNCaP cell line was a gift of $\mathrm{Dr}$ Horoszewicz [2]. Cells were cultured and growth characteristics were analyzed as described previously [5]. The PC-EW human prostate tumor [8], grown in a nude mouse, was kindly provided by Dr van Steenbrugge. 


\section{Steroid and EGF binding studies}

Cytosol of LNCaP cells was prepared and competition studies with steroids were performed as described before [5, 9]. EGF binding to $\mathrm{LNCaP}$ cell monolayers was studied as reported before [5].

\section{Assay of prostate specific acid phosphatase}

The concentration of prostate specific acid phosphatase in culture fluid was assayed immunologically with a commercially available test kit (Enzygnost PAP) from Behring Diagnostica according to the recommendations of the supplier. The limit of detection was $0.2 \mu \mathrm{g}$ enzyme $/$ l. The antibodies of this kit do not cross react with other acid phosphatase isoenzymes.

\section{RESULTS}

Effects of androgen and antiandrogens on growth of $L N C$ CaP cells

LNCaP cells were cultured for 6 days in medium containing $5 \%(\mathrm{v} / \mathrm{v})$ charcoal treated fetal calf serum and various concentrations of different compounds. At day 6, DNA content per culture was determined (Fig. 1). The synthetic, non-metabolizable androgen R1881 was used for study of growth stimulatory effects. In LNCaP cells the effects of $\mathrm{R} 1881$ are mediated by the androgen receptor because progestagen receptors are absent in these cells [5]. R1881 stimulated growth maximally at a concentration of $0.1 \mathrm{nM}$ (3-4 fold increase in DNA content per culture vs control cultures). As observed before [5] stimulation at higher concentration of R1881 is limited. Cyproterone acetate stimulated cell growth twofold at $10 \mathrm{nM}$ while at this concentration RU 23908 had no effect. At a concentration of $100 \mathrm{mM}$, both cyproterone acetate and RU 23908 stimulated $\mathrm{LNCaP}$ cell proliferation to the same extent as $0.1 \mathrm{nM}$ R1881. When $0.1 \mathrm{nM} \mathrm{R} 1881$ was added to the cell cultures in combination with $100 \mathrm{nM}$ cyproterone acetate or $100 \mathrm{nM}$ RU 23908, growth stimulation was similar as observed for R1881 or antiandrogens added alone (Fig. 1). The synthetic glucocorticoid triamcinolone acetonide did not affect growth at concentrations up to $1 \mu \mathrm{M}$.

In a separate series of experiments the effect of long-term cyproterone acetate treatment was

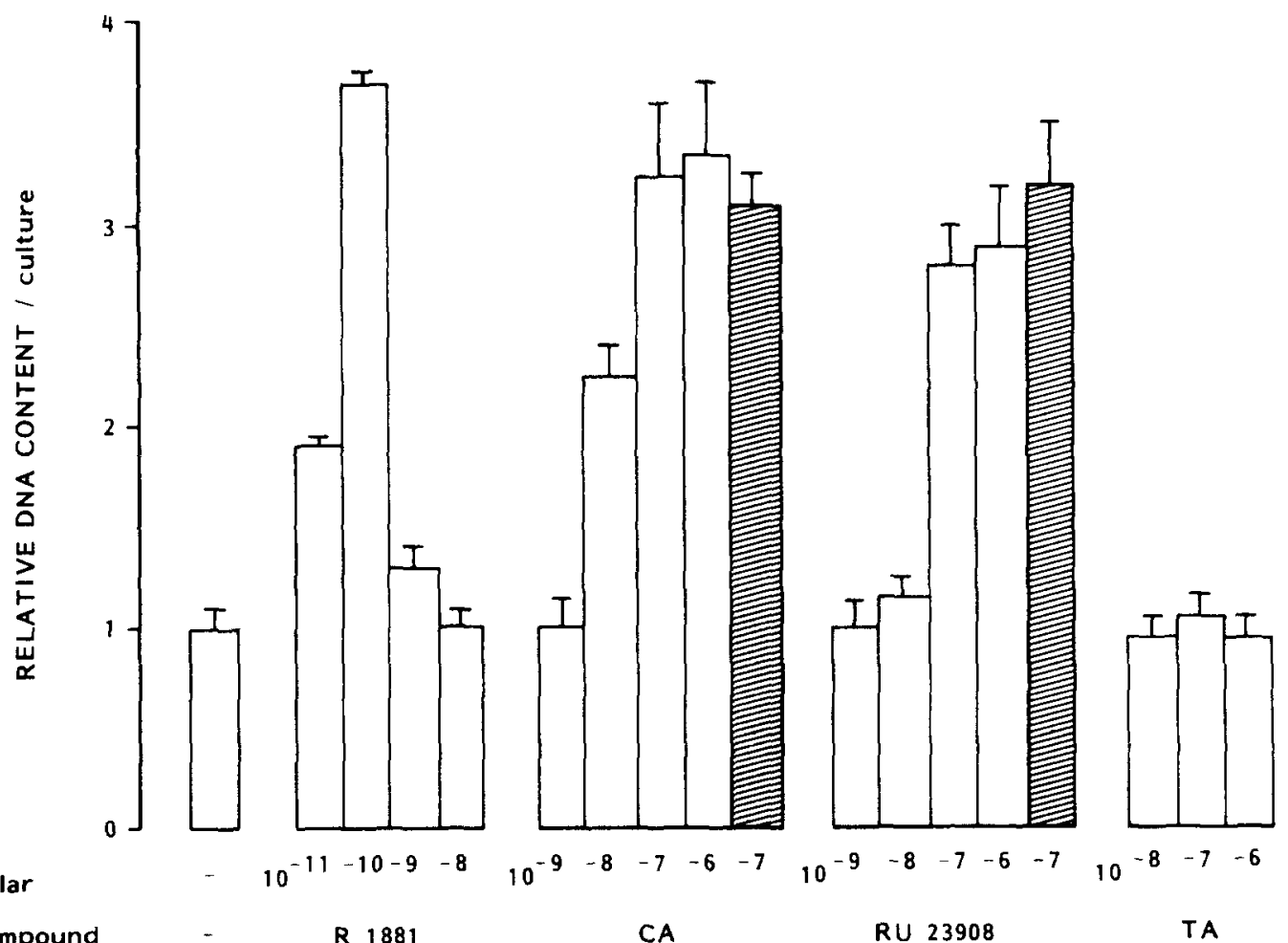

Fig. 1. Effects of various concentrations of R188 I, cyproterone acetate (CA), anandron (RU 23908) and triamcinolone acetonide (TA) on growth of LNCaP cells after 6 days treatment with indicated compounds. Growth is expressed as mean DNA content per culture relative to control cultures (-). Shaded bars show the effect of indicated antiandrogen plus $0.1 \mathrm{nM} \mathrm{R} 1881$. Standard deviations of triplicate experiments are shown. 
Table 1. Relative binding affinity (RBA) of different ligands for the androgen receptor in LNCaP cells and PC-EW tumor

\begin{tabular}{lcc}
\hline & \multicolumn{2}{c}{ RBA value } \\
\cline { 2 - 3 } Ligand & LNCaP & PC-EW \\
\hline R1881 & 100 & 100 \\
Dihydrotestosterone & 88 & 83 \\
Progesterone & 17 & 0.3 \\
Cyproterone acetate & 12.5 & - \\
R5020 & 8.4 & 0.3 \\
Estradiol & 2.4 & 0.2 \\
Ru 23908 & 1.0 & - \\
Triamcinolone acetonide & $<0.1$ & $<0.1$ \\
\hline
\end{tabular}

-., Not determined.

studied. Continuous stimulation was observed for 42 days by both R1881 and cyproterone acetate compared to controls.

\section{Androgen receptor binding}

The binding specificity of the androgen receptor was measured by incubating cytosol of LNCaP cells or PC-EW tumors with $5 \mathrm{nM}$ $\left[{ }^{3} \mathrm{H}\right] \mathrm{R} 1881$ in the presence of various concentrations of steroids and antiandrogens. Relative binding affnity (RBA) values were calculated from competitive binding curves [9] as the ratio of concentration of unlabeled compound and concentration of $\mathrm{R} 1881$ required to inhibit $\left[{ }^{3} \mathrm{H}\right] \mathrm{R} 1881$ binding by $50 \%$ (Table 1 ). The RBA value of $\mathrm{R} 1881$ was set at 100 . In LNCaP cells the affinities of the receptor for both progesterone and R5020 (a synthetic, non-metabolizable
Table 2. Effect of different compounds on EGF binding to LNCaP cells

\begin{tabular}{lc}
\hline Condition & Bound (fmol EGF/mg DNA) \\
\hline Control & $495 \pm 20$ \\
$100 \mathrm{nM}$ triamcinolone acetonide & $480 \pm 25$ \\
$0.1 \mathrm{nM}$ R 1881 & $720 \pm 25$ \\
$100 \mathrm{nM}$ cyproterone acetate & $745 \pm 10$ \\
$100 \mathrm{nM}$ RU 23908 & $690 \pm 10$ \\
\hline
\end{tabular}

progestagen), were much higher than in the transplantable prostate tumor PC-EW. In addition, the receptor obtained from the LNCaP cells showed considerable affinity for estradiol, cyproterone acetate and RU 23908.

\section{Induction of EGF receptors}

Previous studies demonstrated that androgens increase both growth rate and EGF receptor activity in LNCaP cells [7]. EGF binding to $\mathrm{LNCaP}$ cell monolayers was measured after $24 \mathrm{~h}$ treatment with various compounds (Table 2). Both antiandrogens $(100 \mathrm{mM})$ increased EGF binding to LNCaP cells to a level comparable to the binding obtained after addition of R1881 $(0.1 \mathrm{nM})$. Triamcinolone acetonide had no effect on EGF binding to LNCaP cells.

\section{Secretion of prostate specific acid phosphatase}

The time course of secretion of prostate acid phosphatase (PAP) in the culture fluid is shown in Fig. 2. PAP secretion in the culture fluid
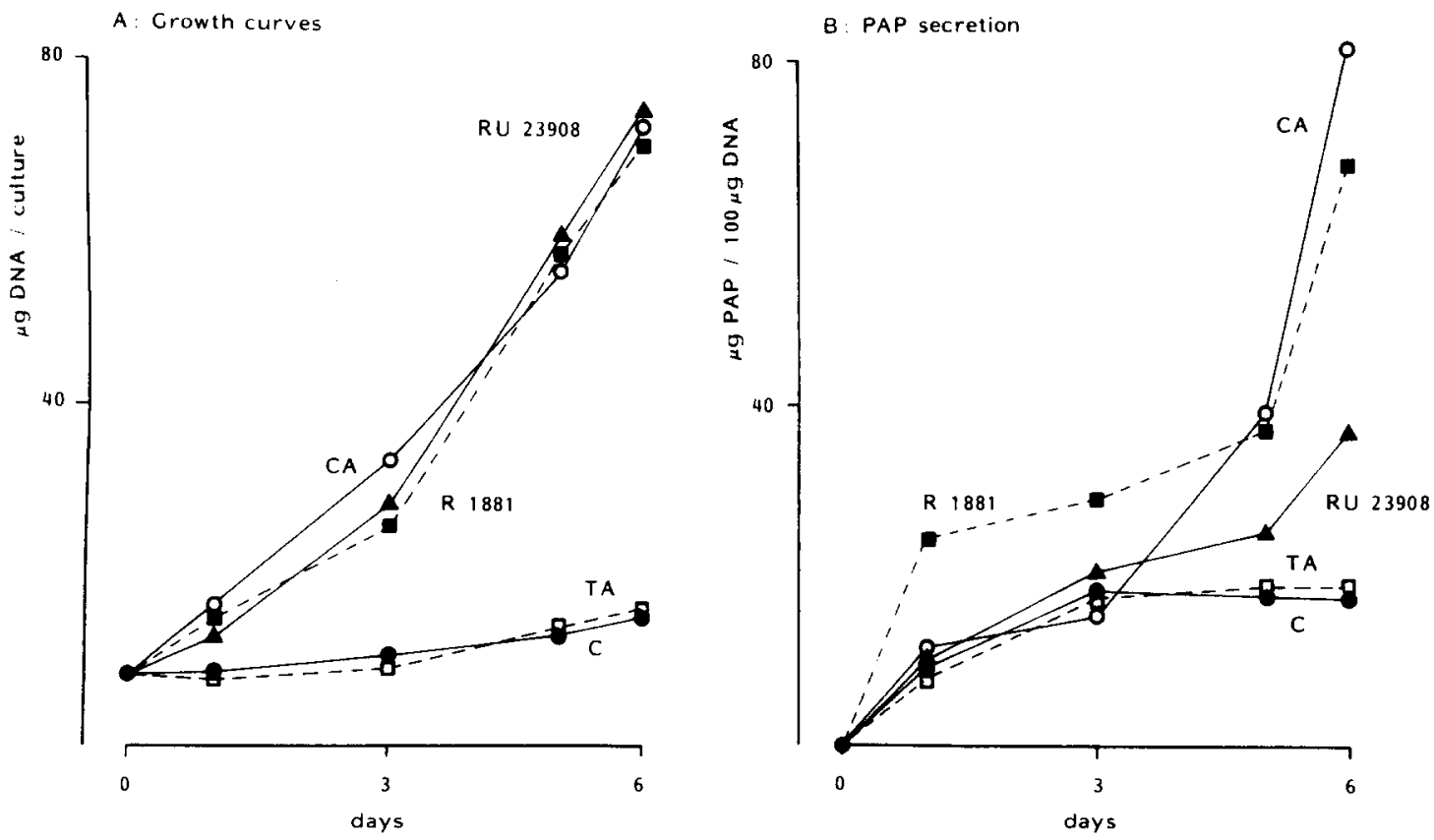

Fig. 2. Growth curves (panel A) and time course of secretion (panel B) of prostate specific acid phosphatase by LNCaP cells. Cells were cultured in the absence $(-0)$ or presence of following compounds: $0.1 \mathrm{nM}$ R1881 ( $-\cdots), 100 \mathrm{nM}$ cyproterone acetate $(\mathrm{O}-\mathrm{O}), 100 \mathrm{nM}$ RU $23908(\boldsymbol{\Delta}-\mathbf{\Delta})$ or $100 \mathrm{nM}$ triamcinolone acetonide $(\square-\cdots-\square)$. 
was calculated and expressed per $100 \mu \mathrm{g}$ DNA in order to correct for differences between cell numbers in control and hormone treated cultures. R1881 and cyproterone acetate were the most potent stimulators of PAP secretion; a 3-4 fold increase after 6 days vs control cells was observed. RU 23908 doubled PAP secretion compared to controls. For control cells and cells treated with triamcinolone acetonide the amount of PAP secreted remained constant after 3 days. We previously reported that $10 \mathrm{nM}$ estradiol also stimulated cell growth [5]. Treatment of LNCaP cells with $10 \mathrm{nM}$ estradiol increased PAP secretion to the same extent as observed after addition of $0.1 \mathrm{nM} \mathrm{R} 1881(64 \mu \mathrm{g}$ $\mathrm{PAP} / 100 \mu \mathrm{g}$ DNA at day 6).

\section{DISCUSSION}

The biological effects of a steroidal and a non-steroidal antiandrogen on LNCaP human prostate tumor cells were compared with effects of the androgen R1881. In contrast to our expectation both cyproterone acetate and RU 23908 exerted striking stimulatory effects on LNCaP cell proliferation. Recently, similar results have been obtained by Wilding et al. [10], who showed agonistic effects of hydroxyflutamide, RU 23908 and cyproterone acetate with respect to growth rate and thymidine incorporation by $\mathrm{LNCaP}$ cells. In a preliminary study from our laboratory [4] stimulatory effects of cyproterone acetate were not seen when cells were cultured in $15 \%$ fetal calf serum. Removal of endogenous steroids from the culture medium (by charcoal stripping) is essential for study of the effect of added steroids on biological characteristics of the cells.

In short-term cultures of human prostatic tissues an enhanced production of PAP can be observed in response to physiological levels of testosterone and dihydrotestosterone [11]. R1881 is the most effective stimulator of PAP expression in LNCaP cells [3]. This may be explained by the facts that R 1881 firmly binds to androgen receptors and is only slowly, if at all, decomposed to inactive products in prostate tissue, in contrast to testosterone and dihydrotestosterone. Schulz et al. [3] showed that estrogens but not triamcinolone acetonide can increase PAP secretion in the culture fluid. We confirm these observations and showed that also antiandrogens stimulated PAP secretion by LNCaP cells. Estradiol and cyproterone acetate were more potent than RU 23908; the differ- ences in stimulatory effect reflected the variation in relative binding affinity to the androgen receptor.

EGF can stimulate the growth of LNCaP cells and androgens increase the number of EGF receptors expressed at the cell surface [7]. EGF acts synergistically with androgen on LNCaP cells to induce cell proliferation, probably due to up-regulation of EGF receptors by androgen [12]. The antiandrogens also exerted stimulatory effects with respect to induction of EGF receptors in LNCaP cells. Both cyproterone acetate and RU 23908 increased EGF receptor levels.

Cytosolic fractions of LNCaP cells and PCEW transplantable prostate tumor tissue differ with respect to the binding specificity of the androgen receptor. The receptor in LNCaP cells has a broad specificity and binds in addition to androgens especially progestagens with high affinity. Cyproterone acetate and RU 23908 compete with androgens for androgen binding sites in LNCaP cells. RU 23908 binds only to androgen receptors while R1881 and cyproterone acetate show considerable affinity for progestin receptors [13]. However, the effects of the two latter ligands are entirely mediated via the androgen receptor since progesterone receptors are absent in LNCaP cells [5]. Cyproterone acetate shows a higher affinity for androgen receptors than RU 23908 [13], in agreement with the observation that cyproterone acetate stimulates growth of LNCaP cells at a lower concentration than RU 23908.

Since the $\mathrm{LNCaP}$ cell line is the only in vitro growing androgen-responsive prostate tumor system of human origin it is not possible to investigate if loss of proper response to antiandrogens by metastatic prostate tumor cells is a general phenomenon for this type of cells in culture. However, it was recently communicated (S. E. Harris et al., J. Trapman et al., unpublished studies) that the androgen receptor in LNCaP cells contains a mutation at aminoacid 877 (thr to ala) in the C-terminal part of the steroid binding domain. The mutation is in an essential conserved region of the steroid binding domain of the receptor. At the similar position in the glucocorticoid receptor a cysteine (cys 754) can be covalently linked to the glucocorticoid triamcinolone acetonide by photo-affinity labeling [14]. One of the mechanisms by which antihormones might antagonize steroid hormones at the molecular level is at the level of transcription. Upon binding of the antihormone 
to the receptor, this complex binds to hormone responsive elements of DNA but fails to induce the transcription activation function. This transcription activation function is probably located in the steroid hormone binding domain of the receptor $[15,16]$. It is tempting to speculate that the mutation in the steroid binding domain of the androgen receptor of LNCaP cells makes it possible for antiandrogens and for different steroids (progestagens, estrogens) to activate this transcription activation function.

The results of the present study imply that further studies on tumor samples obtained from prostate carcinoma are needed to investigate the cause of an unfavorable response to hormonal therapy. In vivo in advanced metastatic prostate cancer the tumors may pass through a stage in which they are stimulated by antiandrogens or estrogens.

\section{REFERENCES}

1. Isaacs J. T.: Development and characteristics of the available animal model systems for the study of prostate cancer. In Current Concepts and Approaches to the Study of Prostate Cancer (Edited by D. S. Coffey). Liss, New York, Vol. 239 (1987) pp. 513-576.

2. Horoszewicz J. S., Leong S. S., Kawinsky E., Karr J. P., Rosenthal H., Ming Chu T., Mirand E. A. and Murphy G. P.: LNCaP model of human prostatic carcinoma Cancer Res. 43 (1983) 1809-1818.

3. Schulz P., Bauer H. W, and Fittler F.: Steroid hormone regulation of prostatic acid phosphatase expression in cultured human prostatic carcinoma cells. Biol. Chem. Hoppe-Seyler 366 (1985) 1033-1039.

4. Berns E. M. J. J., de Boer W. and Mulder E.: Androgendependent growth regulation and release of specific proteins by the androgen receptor containing human prostate tumor cell line LNCaP. Prostate 9 (1986) $247-259$.

5. Schuurmans A. L. G., Bolt J., Voorhorst M. M., Blankenstein R. A. and Mulder E.: Regulation of growth and epidermal growth factor receptor levels of prostate tumor cells by different steroids. Int. J, Cancer 42 (1988) 917-922.

6. Sonnenschein C., Olea, N., Pasanen M. E. and Soto A. M.: Negative controls of cell proliferation: human prostate cancer cells and androgens. Cancer Res. 49 (1989) 3474-3481.

7. Schuurmans A. L. G., Bolt J. and Mulder E.: Androgens stimulate both growth rate and epidermal growth factor receptor activity of the human prostate tumor cell LNCaP. Prostate 12 (1988) 55-63.

8. Hoehn W., Wagner M., Riemann J. F., Hermanek P., Williams W., Walter R. and Schrueffer R.: Prostatic adenocarcinoma PC-EW, a new human tumor line transplantable in nude mice. Prostate 5 (1984) 445-452.

9. Veldscholte J., Voorhorst-Ogink M. M., Bolt-de Vries J., Rooy H. C. J. van, Trapman J. and Mulder E.: Unusual specificity of the androgen receptor in the human prostate tumor cell line LNCaP: high affinity for progestagenic and estrogenic steroids. Biochim. Biophys. Acta 1052 (1990) 187-194.

10. Wilding G., Chen M. and Gelman E. P.: Aberrant response in vitro of hormone-responsive prostate cancer cells to antiandrogens. Prostate 14 (1989) 103-115.

11. Hudson R. W.: The effect of androgens and estrogens on human prostatic acid phosphatase synthesis in tissue culture. Can. J. Physiol. Pharmacol. 59 (1981) 949-954.

12. Schuurmans A. L. G., Bolt J. and Mulder E.: Androgens and transforming growth factor $\alpha$ modulate the growth response to epidermal growth factor in human prostatic tumor cells (LNCaP). Mol. Cell. Endocrinol. 60 (1988) $101-104$

13. Ojasoo T., Delettré J., Mornon J. P., Turpin-VanDycke C. and Raynaud J. P.: Towards the mapping of the progesterone and androgen receptors. J. Steroid Biochem. 27 (1987) 255-269.

14. Carlstedt-Duke J., Strömstedt P.-E., Persson B., Cederlund E., Gustafsson J.-A. and Jörnvall H.: Identification of hormone-interacting amino acid residues within the steroid-binding domain of the glucocorticoid receptor in relation to other steroid hormone receptors. J. Biol. Chem. 263 (1988) 6842-6846.

15. Webster N. J. G., Green S., Jin J. R. and Chambon P.: The hormone-binding domains of the estrogen and glucocorticoid receptors contain an inducible transcription activation function. Cell 54 (1988) 199-207.

16. Guiochon-Mantel A., Loosfelt H., Ragot T., Bailly A., Atger M., Misrahi M. Perricaudet M. and Milgrom E.: Receptors bound to antiprogestin form abortive complexes with hormone responsive elements. Nature $\mathbf{3 3 6}$ (1988) 695-698. 